\title{
Erratum to: Type IV Secretion in Gram-Negative and Gram-Positive Bacteria
}

\author{
Steffen Backert and Elisabeth Grohmann
}

\section{Erratum to:}

S. Backert and E. Grohmann (eds.), Type IV Secretion

in Gram-Negative and Gram-Positive Bacteria, Current Topics in Microbiology and Immunology 413, https://doi.org/10.1007/978-3-319-75241-9

In the original version of the book, the following corrections have been incorporated:

Author name "L.G. Valero" has been corrected to read as "L. Gomez Valero" in chapter "Biological Diversity and Evolution of Type IV Secretion Systems".

Order of the author group "Laurent Terradot, Célia Bergé and Gabriel Waksman" has been changed as "Célia Bergé, Gabriel Waksman, and Laurent Terradot" in chapter "Structural and Molecular Biology of Type IV Secretion Systems".

The erratum book has been updated with the changes.

\footnotetext{
The updated online version of these chapters can be found at https://doi.org/10.1007/978-3-319-75241-9_1 https://doi.org/10.1007/978-3-319-75241-9_2 https://doi.org/10.1007/978-3-319-75241-9 